Vol. 8, Issue 3, pp.1-11, 2020

Published by ECRTD- UK

Print ISSN: 2053-4043(Print), Online ISSN: 2053-4051(Online)

\title{
TOURISM SERVICE QUALITY AFFECTING THE SATISFACTION OF FOREIGN TOURISTS: A CASE STUDY OF HO CHI MINH CITY
}

\author{
Nguyen Van Trai and Nguyen Thanh Van \\ University of Economics Ho Chi Minh City (UEH)
}

\begin{abstract}
In recent years, there is competition among tourist destinations that has been very drastically. This competition of service quality has forced destinations to restructure to increase their competitive and to attract tourists. Therefore, the study goal is to find out the determinants affecting the satisfaction of foreign tourists in Ho Chi Minh City (HCMC). The researchers surveyed 600 foreign tourists who are visiting HCMC destinations and answered 29 questions but sample size of 565 samples processed. The data collected from June 2019 to December 2019 in HCMC. Simple random sampling technique. Cronbach's Alpha and the exploratory factor analysis (EFA) analyzed and used for Structural Equation Modelling (SEM) technique. Foreign tourists' responses measured through an adapted questionnaire on a 5-point Likert scale. Finally, the finding of the study has tourism service quality factor which affecting the satisfaction of foreign tourists in HCMC with significance level 0.01.
\end{abstract}

KEYWORDS: Tourism, service, quality, satisfaction, HCMC.

\section{INTRODUCTION}

In the world, tourism is considered as one of the leading economic sectors, developing at a high speed, attracting the attention of many countries because of the great socio-economic benefits that it brings. This is more evident in the trend of globalization and regionalization with the current international integration of Vietnam. With continuous growth over the past several decades, Vietnam tourism has affirmed to be one of the fastest growing and largest service economic sectors on the world stage, contributing to the development and prosperity of nation.

Economically, the development of tourism has had a positive impact on employment national income which plays a major role in balancing the international payment balance. This is the most direct impact of tourism on the Vietnam economy. Many countries in the region and around the world collect billions of dollars each year through tourism development.

Socially, Vietnam tourism contributes to creating more jobs, stimulating recovery and development of traditional festivals and trade villages. Change the face of many localities where there are developed tourist areas.In 2017, the tourism industry in Vietnam contributed about 396,000 billion VND (equivalent to $7.9 \%$ of GDP); Creating nearly 2.5 million jobs (accounting for $4.6 \%$ of total employment in the country), the export value of passengers reached US $\$ 8.837$ billion (accounting for $4 \%$ of the total export value of the whole country). 
Vol. 8, Issue 3, pp.1-11, 2020

Published by ECRTD- $U K$

Print ISSN: 2053-4043(Print), Online ISSN: 2053-4051(Online)

In 2018, it is gained that international tourists to Vietnam had increased by $22-24 \%$, domestic tourists had increased by $8-10 \%$ and total revenue from other tourist sites that increased by 16$18 \%$. Above mentioned things, the purpose of this study is to find out find out the determinants affecting the satisfaction of foreign tourists in Ho Chi Minh City (HCMC). This study helps tourism managers who apply the research results for improving the satisfaction of foreign tourists in Ho Chi Minh City better in the future.

\section{LITERATURE REVIEW}

\section{Tourism service quality (TSQ)}

Service quality has been defined as a gap between the customer's expectations of a service and the customer's perceptions of the service received (Parasuraman, A., Zeithaml, V.A., \& Berry, L., 1985). The quality of tourism services is the key factor that creates the reputation and brand for each tourist business unit in particular and the tourism industry in Ho Chi Minh City in general. Besides, the affirmation of each tourism business is reflected in the respect of customers, always launching new products, improving the quality of the team working in tourism services, saving money (Assaker, G., Vinzi, V. E, 2011). The quality of tourism services and the components of service quality at tourist attractions (also known as destinations) have been extensively studied on a global scale. It has become one of the most important concepts in scientific research and tourism business practices of enterprises (Chen, C.M, 2011). Tourism service quality is associated with the process of implementation and delivery of services to visitors. Therefore, the service delivery, service style and service delivery will determine whether the service quality is good or bad.

\section{The satisfaction of foreign tourists (SFT)}

Customer satisfaction is the psychological state that customers are in feel about a company (organization) when their expectations are met satisfaction or satisfaction beyond expectations through consumption use the product or service. (Abu Ali, 2012) showed that tourism satisfaction is a comparison of expectations with experiences. Quality expectations are considered expectations or expectations of human. It stems from personal needs, previous experience, from external information such as advertisements, word of mouth from friends and family (Chowdhury, $\mathrm{T}, 2013)$. In which personal needs are factors formed from the awareness of people wanting to satisfy something like needs such as contact information, food and rest.

\section{Reliability (REL):}

Reliability: the ability to perform the promised service dependably and accurately (Kara, A, 2014). The tourism industry is reputable or not, has a large market value, does it fulfill its commitments to tourists, or does it make them feel safe when traveling in Ho Chi Minh City? Tourism industry has a high level of trust, always doing what Ho Chi Minh City has committed. All questions that make tourists' complaints are concerned about the tourism industry and satisfactorily resolved, the visitors' information is confidential... it will increase tourists' satisfaction on quality of services general and quality of tourism services in the HCM City in particular. Therefore, the researchers put this factor into the research model. The hypothesis is following:

Hypothesis H1: Reliability has a positive impact on the tourism service quality of the HCM City. 
Vol. 8, Issue 3, pp.1-11, 2020

Published by ECRTD- UK

Print ISSN: 2053-4043(Print), Online ISSN: 2053-4051(Online)

\section{Empathy (EMP):}

Empathy: the provision of caring, individualized attention to customers (Lordanova, E, 1016). Travelers want the tourism industry to care about themselves, their families, and understand their special needs and interests. Staff cares about Travelers (Osman, Z, 2013). The staff understands the special needs and benefits that travelers expect to meet the needs of travelers. Therefore, the researchers put this factor into the research model. The hypothesis is following:

Hypothesis H2: Empathy has a positive impact on the tourism service quality of the HCM City.

\section{Responsiveness (RES):}

Responsiveness: the willingness to help customers and to provide prompt service (Subrata Banik, 2018). Does the tourism industry provide complete, timely and accurate information to visitors, it is able to solve problems quickly, effectively handle complaints and meet the requirements of travelers? In the course of transactions, when there is a change in information, the tourism industry shall promptly notify tourists (Shaikh, U. A, 2011). The tourism industry provides information for visitors complete and accurate. Officials of the tourism industry are ready to answer questions from travelers. Officials guide documents and procedures in full and easy to understand (Parasuraman, A., Berry, L. L., \& Zeithaml, V. A., 1988). Tourism staff are always attentive during peak hours and attentive staff is available to all travelers. This increases the responsiveness of the tourism industry to visitors. Therefore, the researchers put this factor into the research model. The hypothesis is following:

Hypothesis H3: Responsiveness has a positive impact on the tourism service quality of the HCM City.

\section{Tangibles (TAN):}

Tangibles: the appearance of physical facilities, equipment, personnel and communication materials (Ronglin Xu, 2016). Facilities are modern and comfortable, transactional positions are convenient, staff uniforms are neatly polite... Modern equipment, reasonable arrangement of transaction counters, easy to identify. Good service facilities (parking space, waiting space ....) (Parasuraman, A., Zeithaml, V.A., \& Berry, L., 1985). A neat and polite staff uniform is one of the factors affecting customer satisfaction on tourism service quality. Therefore, the researchers put this factor into the research model. The hypothesis is following:

Hypothesis H4: Tangibles has a positive impact on the tourism service quality of the HCM City.

\section{Competence (COM):}

Competence: the knowledge and courtesy of employees and their ability to convey trust and confidence (Zeithaml, Valarie A. , 1987). Tourists are very interested in the service attitude, professional knowledge of tourism staff... When employees have knowledge, professional competence, staff are courteous and friendly, staff treat fast and accurate business management. (Chutia, S, 2015) Staffs always create trust for visitors, the satisfaction of visitors on the quality of tourism services accordingly increases. Therefore, the researchers put this factor into the research model. The hypothesis is following: 
British Journal of Marketing Studies (BJMS)

Vol. 8, Issue 3, pp.1-11, 2020

Published by ECRTD- $U K$

Print ISSN: 2053-4043(Print), Online ISSN: 2053-4051(Online)

Hypothesis H5: Competence has a positive impact on the tourism service quality of the HCM City.

Hypothesis H6: The tourism service quality has a positive impact on the satisfaction of foreign tourists the in HCM City.

Research model for factors affecting the tourism service quality of the HCM City following:

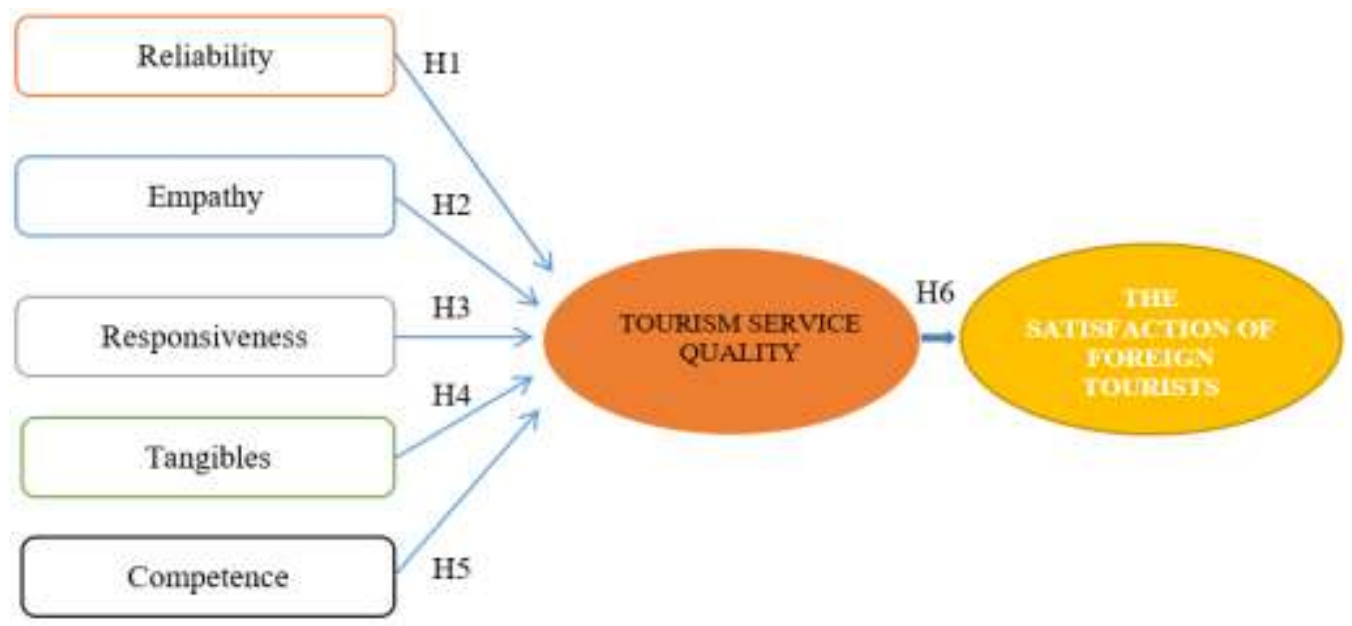

Figure 1

(Source: Researchers proposed)

RESEARCH MODEL FOR FACTORS AFFECTING THE TOURISM SERVICE QUALITY OF THE HCM CITY

\section{METHODS OF RESEARCH}

Research model for factors affecting the tourism service quality of the HCM City comprised the following steps: 
Vol. 8, Issue 3, pp.1-11, 2020

Published by ECRTD- UK

Print ISSN: 2053-4043(Print), Online ISSN: 2053-4051(Online)

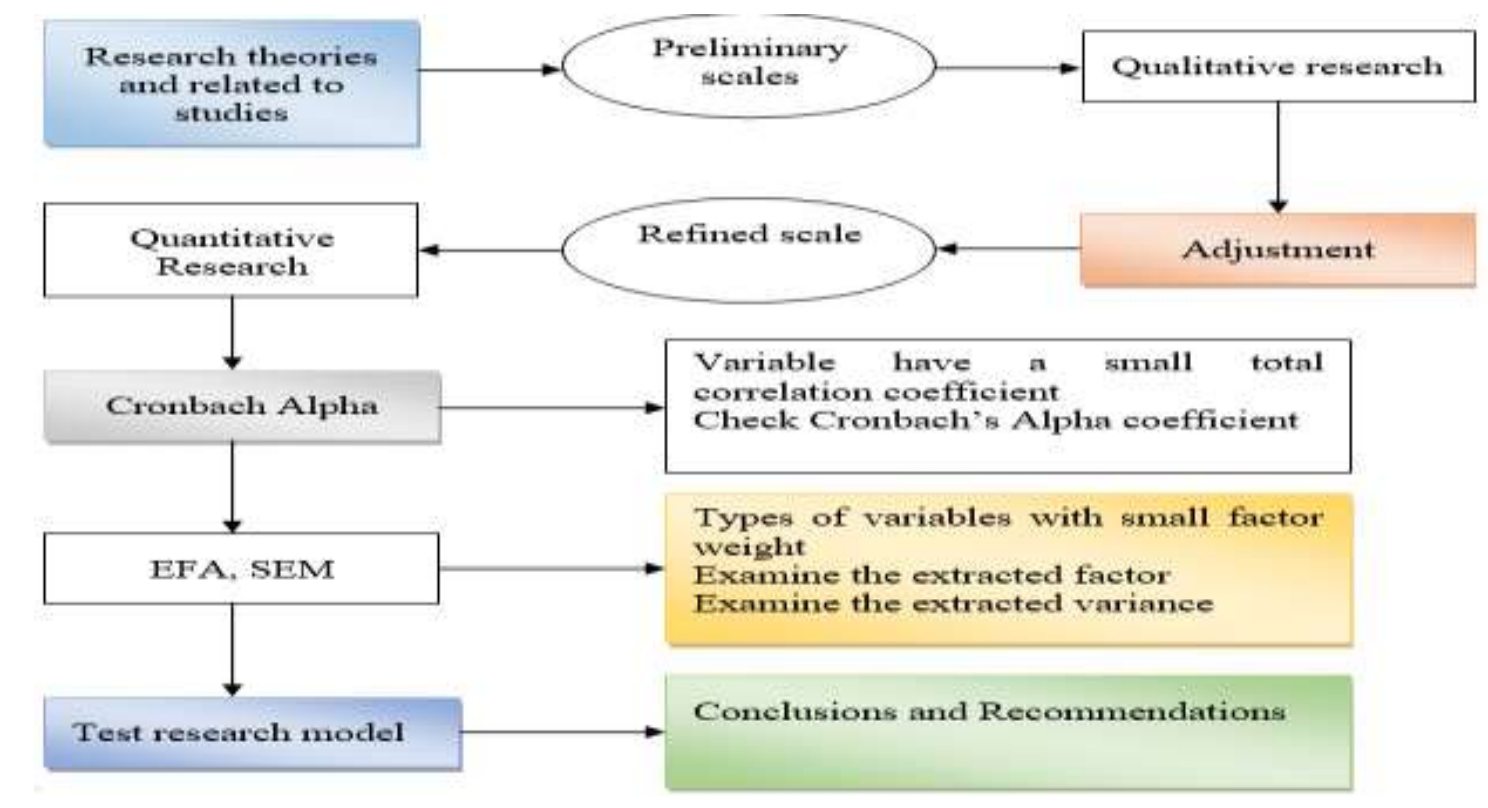

Figure 2

RESEARCH PROCESSING FOR FACTORS AFFECTING THE TOURISM SERVICE QUALITY OF THE HCM CITY

In this study, the researchers applied both qualitative and quantitative. Quantitative method examines numerical data and often requires the use of statistical tools to analyze data collected. Qualitative data is non-numerical and focuses on establishing patterns. Mixed methods are composed of both qualitative and quantitative research methods. Mixed methods allow for explanation of unexpected results. Through the article, the researchers have the research process for factors affecting the tourism service quality of the HCM City. We have many steps following:

(1): The researchers found research theories and related to studies.

(2): The researchers build preliminary scales.

(3): The researchers applied the expert methodology and based on 30 tourism experts' consultation as group discussions are to improve the scale and design of the questionnaire.

(4): The researchers had adjustment a reliability scale with Cronbach's Alpha coefficient and exploratory factor analysis.

(5): The researchers tested and refined reliability scale with Cronbach's Alpha coefficient and exploratory factor analysis. Completed questionnaires were directly collected from the surveyed customers related to tourism because it took them less than 25 minutes to finish the survey. Step

(6): Quantitative Research: There are 600 international tourists. There are 600 international tourists related to the tourism and answered 29 questions but sample size of 565 tourists processed (35 samples lack of information). The primary sources of data collected from June 2019 to December 2019 in HCMC. All data collected from the questionnaire are coded, processed by SPSS 20.0 and Amos.

(7): Cronbach Alpha: any observational variables with a total correlation coefficient greater than 0.3 and Cronbach's Alpha coefficient greater than 0.7 would ensure reliability of the scale. 
Vol. 8, Issue 3, pp.1-11, 2020

Published by ECRTD- UK

Print ISSN: 2053-4043(Print), Online ISSN: 2053-4051(Online)

This method is based on the Eigenvalue, the appropriate factorial analysis and the observed variables in the whole which are correlated when Average Variance Extracted is $>50 \%$, the KMO coefficient is within 0.5 to 1 , Sig coefficient $\leq 5 \%$, the loading factors of all observed variables are $>0.5$. In addition, the researchers testing scale reliability with Cronbach's alpha coefficient and exploratory factor analyses (EFA) were performed. Finally, the least squares method and multiple linear regression used (Hair, Anderson, Tatham, \& Black, 1998). The least squares method is a form of mathematical regression analysis that finds the line of best fit for a set of data, providing a visual demonstration of the relationship between the data points. Each point of data is representative of the relationship between a known independent variable and an unknown dependent variable (Hair, B. B., \& Anderson, 2010).

(8): EFA, SEM: the researchers performed CFA and model testing with Structural Equation Modelling (SEM) analysis. The purpose of CFA helps to clarify: (1) Unilaterality, (2) Reliability of scale, (3) Convergence value, and (4) Difference value. A research model is considered relevant to market data if Chi-square testing is P-value $>5 \%$; CMIN / df $\leq 2$, some cases CMIN/df may be $\leq 3$ or $<5$; GFI, TLI, CFI $\geq 0.9$. However, according to recent researchers' opinion, GFI is still acceptable when it is greater than 0.8 ; RMSEA $\leq 0.08$. Apart from the above criteria, the test results must also ensure the synthetic reliability > 0.6; Average Variance Extracted must be greater than 0.5 (Hair, B. B., \& Anderson, 2010).

(9): The researchers tested research model.

(10): The researchers have conclusions and recommendations.

\section{RESEARCH RESULTS}

The scale reliability tests for factors affecting the tourism service quality of the HCM City

\begin{tabular}{|c|c|}
\hline $\begin{array}{c}\text { Table } 1 \\
\text { CRONBACH'S ALPHA FOR FACTORS AFFECTING THE TOURISM SERVICE QU } \\
\text { HCM CITY }\end{array}$ & ALITY OF THE \\
\hline Items & Cronbach's Alpha \\
\hline REL1: You feel comfortable using travel services in Ho Chi Minh City & \\
\hline $\begin{array}{l}\text { REL2: The tourism industry in Ho Chi Minh City makes transactions accurately and without } \\
\text { errors }\end{array}$ & \\
\hline REL3: The tourism industry in Ho Chi Minh City has good information on visitors & 0.913 \\
\hline $\begin{array}{l}\text { REL4: The tourism industry in Ho Chi Minh City provides services at the time they have } \\
\text { committed }\end{array}$ & \\
\hline REL5: The tourism industry in Ho Chi Minh City has a high reputation among visitors & \\
\hline $\begin{array}{l}\text { EMP1: The tourism industry staffs in Ho Chi Minh City always try to build a good relationship } \\
\text { and pay attention to the needs of each traveler. }\end{array}$ & \\
\hline EMP2: Tourism staffs in Ho Chi Minh City are enthusiastic, friendly with visitors & 0031 \\
\hline EMP3: The tourism staffs in Ho Chi Minh City serve all visitors equally & 0.951 \\
\hline $\begin{array}{l}\text { EMP4: Tourism industry in Ho Chi Minh City always asks, congratulates, gives gifts to visitors } \\
\text { every holiday or personal event (Birthdays, weddings...) }\end{array}$ & \\
\hline $\begin{array}{l}\text { RES1: The tourism industry in Ho Chi Minh City always satisfies all difficulties, questions and } \\
\text { complaints for customers }\end{array}$ & 0.947 \\
\hline RES2: Waiting time for customers to complete procedures (2-3mins) & \\
\hline
\end{tabular}


British Journal of Marketing Studies (BJMS)

Vol. 8, Issue 3, pp.1-11, 2020

Published by $\boldsymbol{E C R T D}-\boldsymbol{U K}$

Print ISSN: 2053-4043(Print), Online ISSN: 2053-4051(Online)

RES3: Simple transaction procedure at Tourism Industry in Ho Chi Minh City

RES4: Tourism in Ho Chi Minh City has a 24-hour hotline

TAN1: Tourism industry in Ho Chi Minh City is spacious and convenient for tourists

TAN2: Tourism industry in Ho Chi Minh City has modern equipment and machinery

TAN3: Papers, forms, usage tickets of the Tourism Industry in Ho Chi Minh City are designed simply and clearly

0.941

TAN4: The tourism industry in Ho Chi Minh City has a reasonable transaction desk layout, convenient for visitors

COM1: Tourism staffs in Ho Chi Minh City handle business properly, quickly and efficiently

COM2: Tourism staffs in Ho Chi Minh City have sufficient knowledge and expertise to advise and answer questions.

COM3: Tourism staffs in Ho Chi Minh City are always polite, kind to visitors

0.853

COM4: Tourism staffs in Ho Chi Minh City are very professional in style and neatly dressed,

polite when communicating

TSQ1: Reliability has a positive impact on the tourism service quality of the HCM City

TSQ2: Empathy has a positive impact on the tourism service quality of the HCM City

TSQ3: Responsiveness has a positive impact on the tourism service quality of the HCM City

TSQ4: Tangibles and competence have a positive impact on the tourism service quality of the HCM City

SFT1: In general, you are satisfied with the quality of travel services in Ho Chi Minh City

SFT2: You will tell friends and relatives about travel services in Ho Chi Minh City

SFT3: You will continue to use travel services in Ho Chi Minh City in the near future

SFT4: You will continue to stay longer in Ho Chi Minh City in the future

(Source: The researcher's collecting data and SPSS 20.0)

Table 1 showed that all of 29 variables surveyed Corrected Item-Total Correlation greater than 0.3 and Cronbach's Alpha if Item deleted greater than 0.7. This showed that all of Cronbach's Alpha are very reliability. Such observations make it eligible for the survey variables after testing scale. This data was suitable and reliability for researching.

\begin{tabular}{|c|c|c|c|c|c|c|c|c|}
\hline \multicolumn{9}{|c|}{$\begin{array}{c}\text { Table } 2 \\
\text { COEFFICIENTS FROM THE STRUCTURAL EQUATION MODELLING (SEM) }\end{array}$} \\
\hline \multicolumn{3}{|c|}{ Relationships } & \multirow{2}{*}{$\begin{array}{c}\text { Coefficient } \\
0.102\end{array}$} & \multirow{2}{*}{ 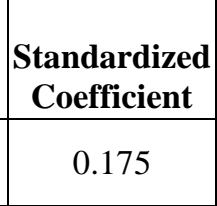 } & \multirow{2}{*}{$\begin{array}{c}\text { S.E } \\
0.025\end{array}$} & \multirow{2}{*}{$\begin{array}{l}\text { C.R. } \\
4.059\end{array}$} & \multirow{2}{*}{$\begin{array}{c}\mathbf{P} \\
* * *\end{array}$} & \multirow{2}{*}{$\begin{array}{c}\text { Conclusion } \\
\text { H3: } \\
\text { Supported }\end{array}$} \\
\hline $\begin{array}{l}\text { Tourism } \\
\text { service quality }\end{array}$ & $<--$ & Responsiveness & & & & & & \\
\hline $\begin{array}{l}\text { Tourism } \\
\text { service quality }\end{array}$ & $<--$ & Empathy & 0.163 & 0.237 & 0.031 & 5.208 & $* * *$ & $\begin{array}{c}\mathrm{H} 2: \\
\text { Supported }\end{array}$ \\
\hline $\begin{array}{l}\text { Tourism } \\
\text { service quality }\end{array}$ & $<--$ & Reliability & 0.346 & 0.411 & 0.043 & 8.092 & $* * *$ & $\begin{array}{c}\text { H1: } \\
\text { Supported }\end{array}$ \\
\hline $\begin{array}{l}\text { Tourism } \\
\text { service quality }\end{array}$ & $<--$ & Competence & 0.135 & 0.165 & 0.032 & 4.194 & $* * *$ & $\begin{array}{c}\text { H5: } \\
\text { Supported }\end{array}$ \\
\hline $\begin{array}{l}\text { Tourism } \\
\text { service quality }\end{array}$ & $<---$ & Tangibles & 0.079 & 0.134 & 0.026 & 3.039 & 0.002 & $\begin{array}{c}\text { H4: } \\
\text { Supported }\end{array}$ \\
\hline $\begin{array}{l}\text { Satisfaction of } \\
\text { foreign tourists }\end{array}$ & $<---$ & $\begin{array}{l}\text { Tourism } \\
\text { service quality }\end{array}$ & 0.350 & 0.250 & 0.061 & 5.762 & $* * *$ & $\begin{array}{c}\text { H6: } \\
\text { Supported }\end{array}$ \\
\hline
\end{tabular}

Note: Significant at 1 percent (All t-tests are one-tailed)

(Source: The researcher's collecting data and SPSS 20.0, Amos) 
Vol. 8, Issue 3, pp.1-11, 2020

Published by ECRTD- UK

Print ISSN: 2053-4043(Print), Online ISSN: 2053-4051(Online)

Table 2 showed that column "P" $<0.01$ with significance level 0.01 and column "Conclusion" $\mathrm{H} 1$ : supported; H2: supported; H3: supported; H4: supported; H5: supported. H6: supported. This showed that five factors affecting the tourism service quality with significance level 0.01 . And the tourism service quality affecting the satisfaction of foreign tourists in HCM City with significance level 0.01 .

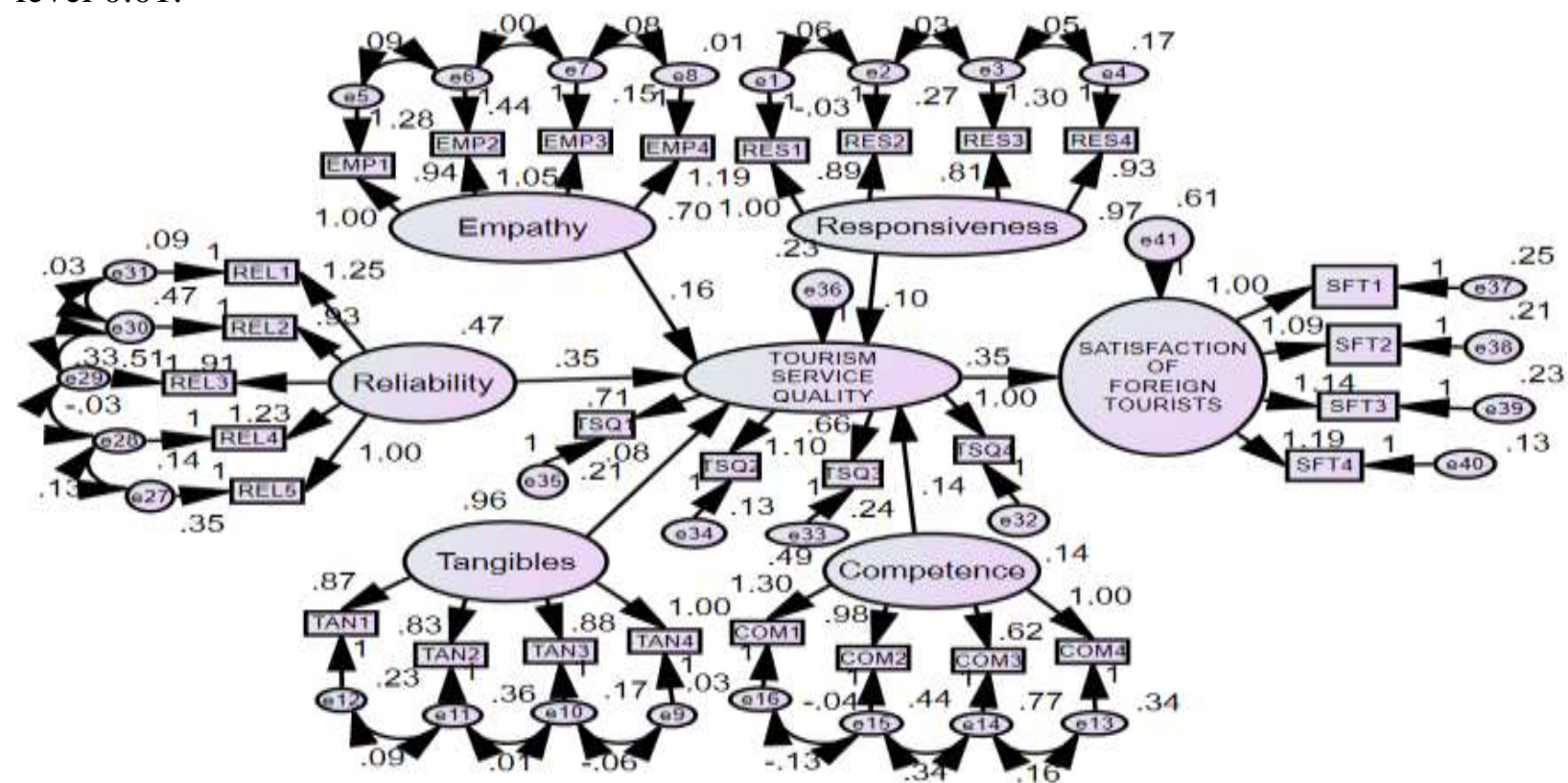

(Source: The researchers' collecting data, SPSS 20.0 and Amos)

Figure 3

\section{THE STRUCTURAL MODEL SHOWING THE STRUCTURAL LINKAGE BETWEEN COMPONENTS}

Chi-square $=1447.031 ; \mathrm{df}=355 ; \mathrm{p}=0.000 ;$ Chi-square $/ \mathrm{df}=4.076 ; \mathrm{GFI}=0.853 ; \mathrm{TLI}=$ $0.914 ; \mathrm{CFI}=0.924 ; \mathrm{RMSEA}=0.074$.

\section{CONCLUSIONS \& MANAGERIAL IMPLICATIONS}

\section{Conclusions}

Sustainable tourism development is a worldwide trend. The researchers had been assessing the satisfaction of tourists for tourism in Ho Chi Minh City. Besides, the researchers had explored the determinants affecting the satisfaction of foreign tourists in Ho Chi Minh City (HCMC). The researchers surveyed 600 foreign tourists who are visiting HCMC destinations and answered 29 questions but sample size of 565 samples processed. The data collected from June 2019 to December 2019 in HCMC. Simple random sampling technique. Cronbach's Alpha and the exploratory factor analysis (EFA) analyzed and used for Structural Equation Modelling (SEM) 
Vol. 8, Issue 3, pp.1-11, 2020

Published by ECRTD- UK

Print ISSN: 2053-4043(Print), Online ISSN: 2053-4051(Online)

technique. Foreign tourists' responses measured through an adapted questionnaire on a 5-point Likert scale such as conventions: 1: Completely disagree, 2: Disagree, 3: Normal; 4: Agree; 5: completely agree. Finally, the finding of the study has tourism service quality factor which affecting the satisfaction of foreign tourists in HCMC with significance level 0.01. In the coming time, Ho Chi Minh City needs to develop the tourism industry by investing in the development of community-based tourism infrastructure associated with the conservation of natural resources values, course; preserving and promoting the traditional cultural values of ethnic groups that also need to raise the awareness of those involved in tourism activities. Because tourism development is not only a duty of local governments, it is necessary to join hands and contribute to the development of community based tourism. The researchers had managerial implications for tourism policymaker of HCMC continued to improve the satisfaction of foreign tourists following.

\section{Managerial implications}

This study identifies the factors that influence and assess tourist satisfaction with tourism service quality in Ho Chi Minh City. Based on the theoretical frameworks, empirical studies and qualitative research results, the authors propose a research model consisting of five factors: Responsiveness; Empathy; Reliability; Competence and Tangibles. Based on standardized coefficient, HCMC tourism should improve recommendations the following:

Managerial implication for reliability is 0.411. Based on the above research results, tourism industry leaders of Ho Chi Minh City need to increase the reliability as follows: (1) Staffs need to understand the needs and expectations of tourists at the tourist destination. (2) The service staffs must be professional in both knowledge and service skills at the destination. (3) Travelers' issues should be fully addressed at the destination. (4) Tourism areas must diversify and make available the services provided at the destinations. (5) Tourism areas must be consistent and reliable in providing services at tourist attractions. Ho Chi Minh City need to improve the awareness of the community at the tourist destination that will be improved the attitude and attitude towards tourists will contribute to creating a beautiful image in the minds of visitors. On the other hand, the management team in tourism businesses and service staff with good competence will have many high quality tourism products which is the basic things to improve the satisfaction and loyalty of visitors. Thereby, Ho Chi Minh City need to attract more visitors and extend the length of stay.

Managerial implication for empathy is $\mathbf{0 . 2 3 7}$. Based on the above research results, tourism industry leaders of Ho Chi Minh City need to strengthen the empathy as follows: (1) Visitors should be respected when visiting tourism. (2) Tourists need to be concerned and carefully guided when visiting tourism sites. (3) The attendant must show an interest in the needs of the tourist at the destination. (4) Managers and staffs should promptly handle incidents to please the tourist at the site

Managerial implication for responsiveness is $\mathbf{0 . 1 7 5}$. Based on the above research results, the tourism industry in Ho Chi Minh City needs to improve the service capacity as follows: (1) The goods and food displayed for sale in the sights that should be of good quality, hygienic and safe at the tourist sites. (2) Tourism industry of Ho Chi Minh City performs well in security, order, safety and insurance for visitors. (3) Tourism management and staffs of Ho Chi Minh City need to fully 
Vol. 8, Issue 3, pp.1-11, 2020

Published by ECRTD- UK

Print ISSN: 2053-4043(Print), Online ISSN: 2053-4051(Online)

implement the services as committed at the tourist destination. Besides, Ho Chi Minh City invests in training and improving the quality of human resources and local communities at key tourist destinations. This is as a basic foundation to improve tourism business efficiency for tourism businesses as well as tourism business households. Thereby, Ho Chi Minh City continues contributing to the development of destination tourism, greatly contributing to the development of tourism economy of the City as well as the locality where the tourist attraction is located.

Managerial implication for competence is $\mathbf{0 . 1 6 5}$. Based on the above research results, tourism industry leaders of Ho Chi Minh City need to increase the response level as follows: (1) The needs of tourists need to be met quickly and fully at the tourist destination. (2) At any time, services need to be met as fully and quickly as possible at the tourist site. (3) The supportive and supplementary services must meet the individual requirements of each traveler. (4) Staffs are required to inform travelers exactly when the service will be provided at the destination.

Managerial implication for tangibles is $\mathbf{0 . 1 3 4}$. Based on the above research results, tourism industry leaders of Ho Chi Minh City need to strengthen the tangible facilities as follows: (1) Need equipment, utensils to serve tourists at tourist attractions. (2) Tourism constructions: parking lots, waiting rooms, ticket rooms, souvenir shops, restaurants and toilets that must be clean and green at tourist sites. (3) Information and guidance in the tourist area: signs, information boards, leaflets must be clear and noticeable at the tourist site. (4) tourism industry leaders of Ho Chi Minh City continue building beautiful landscapes and preserving, embellishing and arranging landscapes in beautiful and reasonable tourist destinations. (5) tourism industry leaders of Ho Chi Minh City have entertainment spots that should have a reasonable transaction desk layout, convenient for travelers at tourist destinations.

Finally, Ho Chi Minh City needs to build a synchronous system of material and technical foundations for tourism with high quality. In particular, Ho Chi Minh City continues investing in interesting entertainment facilities to serve tourists, prioritizing the construction of hotels of 3 or more stars with a minimum scale of 60 rooms including a restaurant inside the hotel to ensure better business performance. Ho Chi Minh City continues constructing high-class service works capable of organizing big conferences and events.

\section{REFERENCES}

Abu Ali (2012). The impact of service quality on tourist satisfaction in Jerash. Interdisciplinary Journal of Contemporary Research in Business, 3(12), 164-187.

Assaker, G., Vinzi, V. E. (2011). Examining the effect of novelty seeking, satisfaction, and destination image on tourists' return pattern: A two factor, non-linear latent growth model. Tourism Management, 32(1), 890-901.

Chen, C.M. (2011). Tourist behavioural intentions inrelation to service quality and customer satisfaction in Kinmen National Park, Taiwan. International Journal of Tourism Research, 13(1), 416-432.

Chowdhury, T. (2013). Promoting Public Private Partnership for Development of Tourism Sector of Bangladesh: An Exploratory Study. European Journal of Business and Management, 5(32), 194-202. 
Vol. 8, Issue 3, pp.1-11, 2020

Published by $\boldsymbol{E C R T D}-\boldsymbol{U K}$

Print ISSN: 2053-4043(Print), Online ISSN: 2053-4051(Online)

Chutia, S. (2015). Prospects and Problems of Tourism Industry in Assam. International Journal of Innovative Research in Science, Engineering and Technology, 4(2), 633-638.

Hair, B. B., \& Anderson (2010). Multivariate Data Analysis (7th ed.). New York: US: Pearson Prentice Hall.

Hair, J., Anderson, R., Tatham, R., \& Black, W. (1998). Multivariate Data Analysis with Readings. US: Prentice-Hall: Upper Saddle River, NJ, USA.

Kara, A. (2014). Supermarket self checkout service quality, customer satisfaction, and loyalty: empirical evidence from an emerging market. Journal of Retailing and Consumer Services, 21(2), 118-129.

Lordanova, E. (1016). Tourism destination image as an antecedent of destination loyalty: The case of Linz, Austria. European Journal of Tourism Research, 16(1), 214-232.

Osman, Z. (2013). Mediating effect of customer satisfaction on service quality and customer loyalty relationship in Malaysian rural tourism. International Journal of Economics and Management Studies, 2(1), 25-37.

Parasuraman, A., Berry, L. L., \& Zeithaml, V. A. (1988). The service-quality puzzle. Business horizons, 35-43.

Parasuraman, A., Zeithaml, V.A., \& Berry, L. (1985). conceptual model of service quality and its implications for future research. The Journal of Marketing, 41-50.

Ronglin Xu (2016). A Study of Tourist Loyalty Driving Factors from Employee Satisfaction Perspective . American Journal of Industrial and Business Management, 6(1), 1122-1132.

Shaikh, U. A. (2011). Impact of service quality on customer satisfaction: evidences from the restaurant industry in Pakistan. Management \& Marketing, 9(2), 343-355.

Subrata Banik (2018). Factors Affecting Tourist Satisfaction in Bangladesh. Journal of Management and Science, 8(2), 57-64.

Zeithaml, Valarie A. (1987). Defining and Relating Price, Perceived Quality, and Perceived Value. PercMarketing Science Institute, Cambridge, 87-101. 